\title{
Polymeric materials used in the preservation of historical stone buildings
}

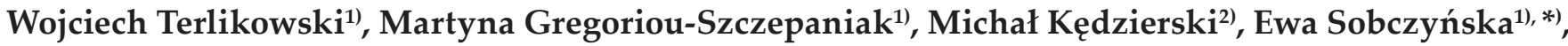 \\ Kacper Wasilewski ${ }^{1)}$
}

DOI: dx.doi.org/10.14314/polimery.2020.4.5

\begin{abstract}
In this review, authors discuss the pre-requisites to be fulfilled for the preservation of stone monuments, referring both to the selection of appropriate materials (compatibility principle) as well as to the repair process itself. Since ancient times, a wide range of natural and synthetic polymers has been employed for stone recovery purposes. The paper presents the examples of most commonly used polymeric materials along with recent trends in conservation of stone materials.
\end{abstract}

Keywords: stone masonry monuments, preservation, natural polymers, synthetic polymers.

\section{Materiały polimerowe wykorzystywane do konserwacji zabytkowych konstrukcji kamiennych}

Streszczenie: $\mathrm{W}$ artykule o charakterze przeglądowym przedstawiono zasady obowiązujące przy konserwacji zabytków z kamienia, odnoszące się zarówno do doboru odpowiednich materiałów (zasada kompatybilności), jak również samego procesu naprawczego. Opisano szeroką gamę polimerów naturalnych i syntetycznych stosowanych w celach rekonstrukcyjnych oraz główne trendy w konserwacji zabytków kamiennych.

Słowa kluczowe: zabytkowe konstrukcje kamienne, konserwacja, polimery naturalne, polimery syntetyczne.

Preservation of stone masonry monuments, a part of the architectural and structural heritage, is frequently focused on protection or, in case of severe damaged materials, recovery actions. Such a treatment is particularly necessary for structures that are a part of archeological excavations or of archaeological open-air museums. Those monuments usually require strengthening of an internal structure of stones, as well as a whole masonry components (such as walls, vaults, etc.). The main issue that is addressed with this treatment is protection against the degradation that may come from several origins. The most common structures and materials that appear in archaeological tranches are highly degraded due to their age and long-term influence of destructive agents, such as: environment or climate impact, biological or mechanical deterioration or, in case of better preserved structures, an inadequate maintenance. In all of this actions, both strengthening and protection of masonry monuments, polymers have some important auxiliary function. They

\footnotetext{
1) Warsaw University of Technology, Faculty of Civil Engineering, al. Armii Ludowej 16, 00-637 Warsaw, Poland.

2) ŁUKASIEWICZ Research Network - Industrial Chemistry Research Institute, Rydygiera 8, 01-793 Warsaw, Poland.

*) Author for correspondence: e.sobczynska@il.pw.edu.pl
}

are not only ingredients that improve the properties of repair mortars but also materials that are used for consolidation of deteriorated stone as well as hydrophobization. In this paper, authors present the examples of most commonly used polymeric materials along with recent trends in conservation of stone materials.

Masonry is a structure that is composed of masonry units (e.g., sorted or unsorted stones, semiregular units or regular units - ashlars or blocks) that originate from different rocks with various physical, chemical and mechanical characteristics. The units are assembled in a proper way (in a specific pattern called masonry bond) and, usually but not necessarily, joined together with mortar. Therefore, the given definition of masonry implicates a complex state of conservation, in particular, the ancient masonry, which usually is in severely damaged conditions. Based on the type of masonry and the masonry bond, the degradation can refer to overall structure, its internal or external composition, the failure of a mortar's adhesion or even failure of each masonry units (in case of an ancient masonry a frequently observed phenomenon is a granular disintegration of masonry units). An irregular or semiregular masonry, that consists of small unsorted stone units, are usually internally consolidated with a low strength mortar, in which an easily accessible material (such as lime, clay or gyp- 
sum) is used as a binder. The mortar is the masonry component that features the biggest influence on structural durability. The above mentioned, low strength mortars have also low durability and internal integrity. Hence, the irregular masonry is vulnerable to the weather influence, such as rainfalls, snowfalls or subzero temperatures. The regular masonry (e.g. ashlar masonry) is usually more durable since its integrity mostly depends on physical and chemical characteristics of stones that were used for masonry units.

The conservation work should be preceded by a proper diagnostic phase. It should result not only from the assessment of the technical conditions of the structure and its components (mortar and masonry units), but also from the analysis of the physical, chemical and mechanical characteristics, as well as from the identification of the bricklaying technique and the masonry bonds. Then the proper conservation technique can be applied. Those interventions can address one or more of three different aspects - repair, strengthening or protection. Among those actions, the following could be specified:

- Reprofiling - reprofiling of existing masonry parts with the anastylosis method (recreation of a structure with all original elements and identical to its original shape). Masonry reprofiling should be carried out in four main stages. First, the top layer of the structure is rebuilt. In the next two steps, a finishing mortar is placed to a fresh grout (pointing) and, after hardening, the joints are again complimented with a finishing mortar. The final action is mechanical cleaning.

- Bonding - integration of internal wall structure by injection method.

- Reconstruction using anastylosis or semianastylosis method (recreation of a structure with all original elements but not identical to its original shape).

- Hydrophobization.

In the preservation of stone masonry monuments the following principles must be applied:

- compatibility of materials - all materials used in conservation activities should have the same (or similar) mechanical and physical properties as the original one;

- reversibility of methods and materials - all conservation activities should be carried out in such a way and using such materials that can be removed in the future, restoring the original state;

- distinctiveness - not original materials cannot dominate over the original one.

In this paper, we present selected examples of using polymeric materials in the preservation of historical stone buildings. The literature devoted to this topic is very extensive, a search for citations in Scopus database using the string of keywords ["polymer" AND ("building" OR "stone") AND ("conservation" OR "restoration" OR "preservation")] resulted in a total of 546 papers, including 212 results from the most recent five years. Therefore, this review is limited to a number of examples illustrating various types of natural and synthetic polymers which have found application in this field, especially in case of mortars used.

\section{NATURAL POLYMERS}

Since ancient times, a range of natural additives has been used to improve the properties of mortars. The simplest were chopped straw and various types of plant fibers [1], which increased mortar resistance to shrinkage cracking and mechanical damage. The reinforcement material was cellulose, composed of polysaccharide chains, which form microfibrils bound together by amorphous lignin and hemicellulose. The individual cellulose microfibrils are few nanometers in diameter being aggregated into bundles and macrofibrils that constitute complex multilayered structure of plant cell wall [2]. Accordingly to results described in [1] the addition of a nopal, both as powder and as mucilage, results in an increase of the mechanical resistance by a factor of 1.5 in comparison to the reference sample.

Leaves, previously left to rot, were mixed with clay and lime in India. They contained a number of ingredients beneficial from the viewpoint of the mortar properties, including wax, increasing the resistance to water sorption and fibers protecting the matrix from cracking. As a result, a material with increased strength and durability was obtained [3].

In addition to fibrous reinforcing materials, naturally occurring polysaccharides, proteins and fats were also used, such as dairy products, eggs, cereals, animal blood, glutinous rice, oils and fruit pulp [4].

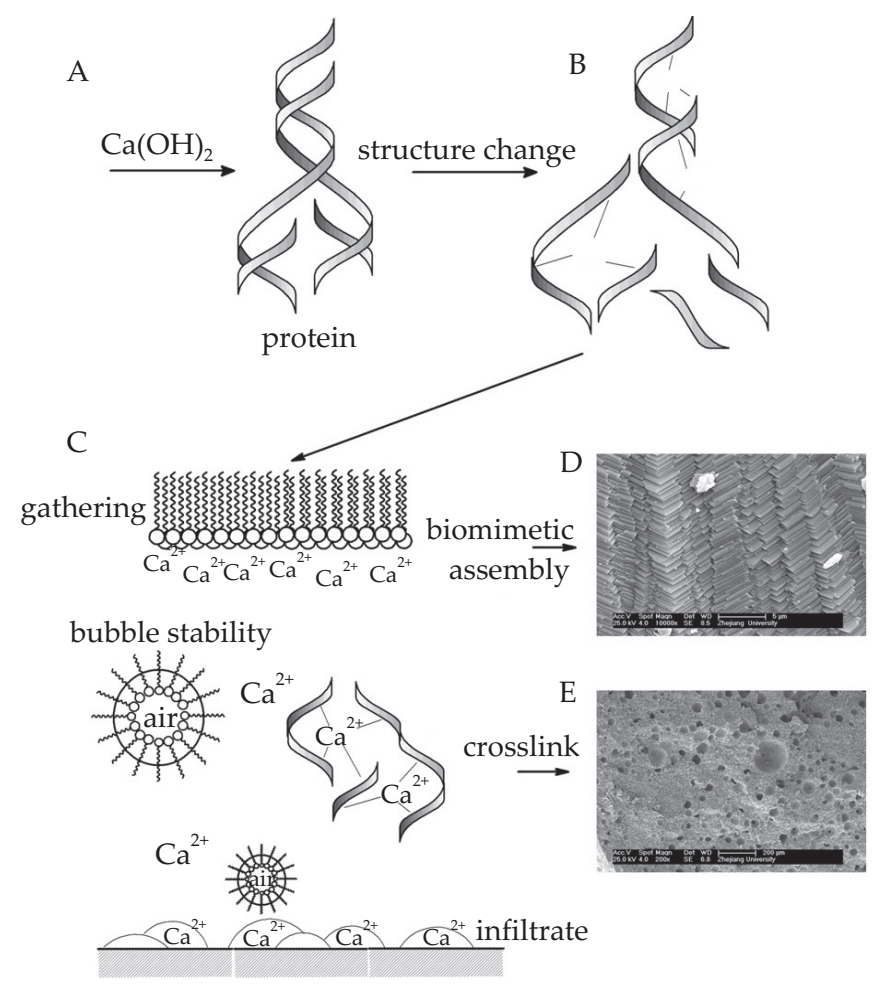

Fig. 1. Schematic of blood interaction with lime mortar [6] 


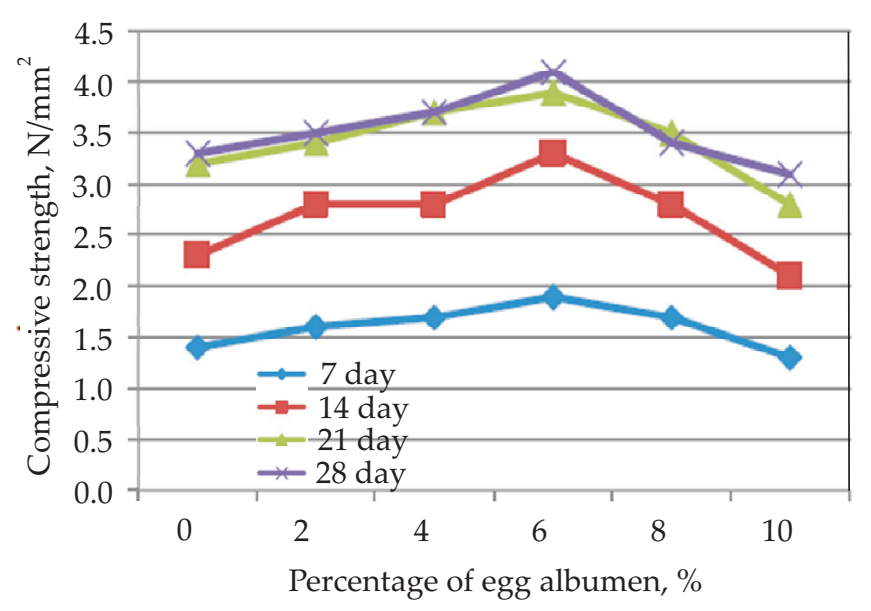

Fig. 2. Compressive strength of lime mortar with different percentages of egg albumen [10]

Crop flour and blood have been used as binders in the mortars of Chinese wooden buildings. Investigations on mortar samples from the Old Summer Palace, the Eastern Royal Tombs of the Qing Dynasty and the Taiyuan Confucius Temple, showed the presence of proteins, including cattle blood and pig blood [5].

In India, flax and sugar were utilized as special additives to mortars [3]. The proteins contained in the blood could control the crystal growth and form a compact skin layer on the surface of hardening render. They might act as setting retarders through a complexation of calcium ions. Also, proteins played a role of air-entraining agents and improved the adhesiveness as well as hydrophobic properties of cement mortar [6, 7] The processes taking

a)

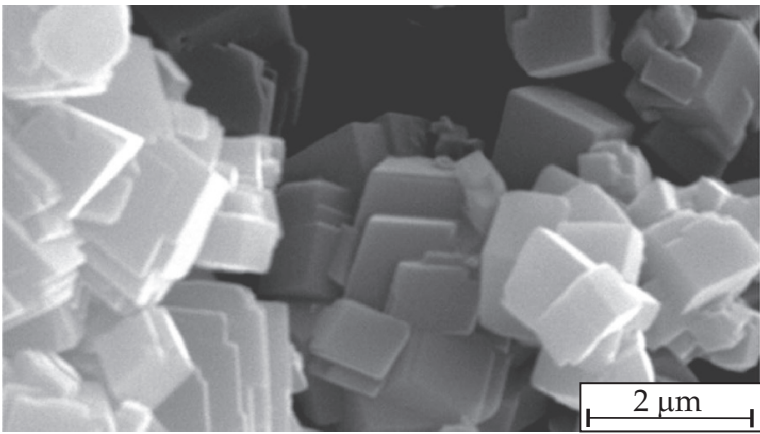

c)

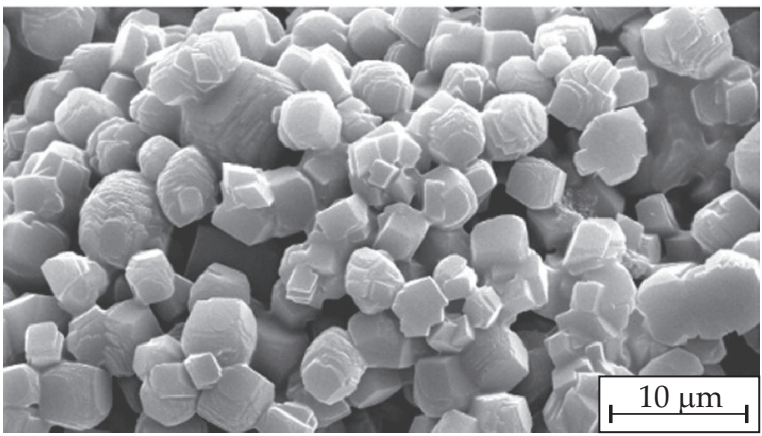

place when blood is added to the mortar are schematically shown in Fig. 1.

Dairy products such as milk, curd and whey have been added to mortars since ancient times. Casein, the main phosphoprotein of bovine milk, may act as plasticizer or stiffening agent, improving the workability and consistency of cementitious mortars [8]. Also an animal glue was used, which multiplies compressive strength [1].

Egg white was detected in the ancient traditional mortar, widely used in different areas in China [9]. The study of Mydin showed that the addition of up to $6 \%$ egg white increases the workability, compressive and flexural strength of lime mortar (Fig. 2). This was attributed to the acting of egg proteins as a lubricant making the mortar easier to compact and filling the smaller voids inside the mortar [10].

An example of polysaccharide additive used as architectural material in ancient China was sticky rice [11]. By its introduction the physical properties, mechanical strength, and compatibility of lime mortar were significantly improved. An analytical study showed that amylopectin, highly branched polymer of glucose, was the rice ingredient responsible for the strength and durability of the mortar used to build the Great Wall and Tomb of Deng Count from the Southern and Northern Dynasty (420-589 AD). Amylopectin acted as an inhibitor, resulting in controlled growth of the calcium carbonate crystal with formation of microporous structure (Fig. 3) [12].

The advantage of using sticky rice compared with other natural additives (brown sugar, tung oil) was its lower cost, easier transport and storage.

b)

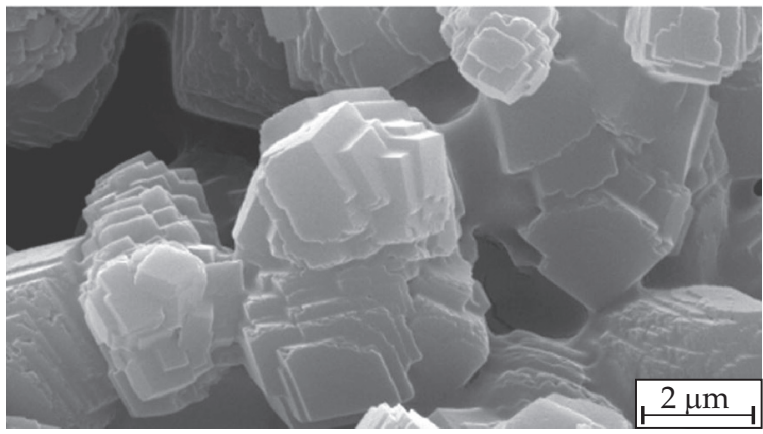

d)

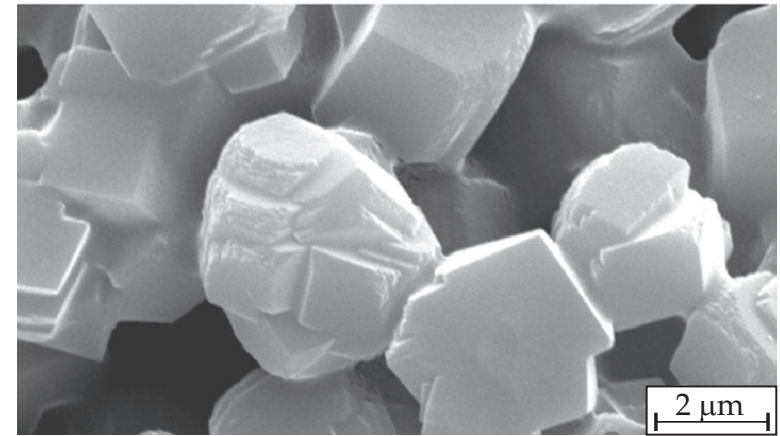

Fig. 3. SEM micrographs showing the morphology of precipitated $\mathrm{CaCO}_{3}$ under different conditions: a) pure lime, b) lime with polycarboxylate ether type plasticizer (C-SP) and $1 \mathrm{wt} \%$ sticky rice, c) lime with C-SP and $3 \mathrm{wt} \%$ sticky rice, d) magnified view of c) [13] 
Other natural additive for mortars, containing polysaccharides, which was used in historic buildings in Mexico is cactus juice extracted from the Opuntia ficus-indica. The advantage of cactus based admixtures is their biodegradability, non-toxicity and high availability in different parts of the world. Using the mucilage from cactus as additive allows to improve mechanical, physical and strength properties of lime, especially compressive and bending strength as well as hydrophobicity [14].

Another studies were performed to investigate the influence of incorporation of Cissus glauca Roxb, a trailing herb that was historically used in several parts of India [12]. The main objectives of the study were an evaluation of the influence of admixture on mechanical strength, the microstructure and porosity of the mortars, as well as an assessment of durability through capillarity water/salt absorption of mortars. Except the regular mechanical and durability tests, to study the microstructure of the modified mortars, the following tests were performed: Fourier transform infrared spectroscopy (FT-IR), X-ray diffraction (XRD), Scanning electron microscopy (SEM). The investigated mortars varied in concentration of natural admixture and fermentation periods of the herb to the mortar mix. The results of the investigation show the increase of the compressive strength, up to $60 \%$, and the flexural strength, up to $45 \%$. Due to hydrophobicity offered by the admixture, the water absorption was reduced by almost $20 \%$. It also resulted in the blockade of the capillary pores, which reduce the capillarity suction and can protect structures from the damage due to rain or the other weathering agents. Moreover, the hydrophobic properties result in a reduction of salts penetration and the associated damages.

Natural oils and fats were among the most common types of water-repellent additives used in mortars in the antiquity. As it was shown in [1], olive oil used as additive reduces the pore size and results in a hydrophobic mortar with significantly improved water resistance (Fig. 4).

The mortar with added tung oil was often used to fill gaps in wells, tombs or wooden boats, protecting them against water leakage. Beeswax, vegetable oils, paraffin or ceresin are often used in conservation practice, providing the hydrophobic properties to protected stone elements. Because of high elasticity and low mechanical resistance, they do not have a destructive effect on the stone (different coefficient of thermal expansion) [15].

\section{SYNTHETIC POLYMERS}

Among the synthetic polymers used for conservation, the most employed are epoxy and acrylic polymers, organic silicones as well as fluoropolymers, differing in their properties and their impact on treated objects [16].

Epoxy resins can effectively penetrate and seal porous substrates (ideal to strengthen porous stones such as limestones and sandstones), when polymerized they form a crosslinked network with outstanding mechanical strength. The first reports on the use of epoxy-amine systems for the consolidation of deteriorated stone were published in 1960s [17]. First epoxy bound replica of a pair of sculptures is shown in Fig. 5. Since then, various epoxy systems in the form of solutions or dispersions, containing plasticizers, fillers and pigments have been applied to in the conservation of stone materials [18, 19]. The most extensively used epoxy resins are based on aromatic monomers such as bisphenol A (dian) and its oligomers, which are characterized by a favorable ratio of strength to the amount of introduced resin. However, the use of dian resins is limited due to their low resistance to light exposure. Aliphatic and cycloaliphatic resins as well as polyglycidyl esters of cyclic alcohols and acids do not exhibit this drawback. Polyglycidyl esters have lower a)

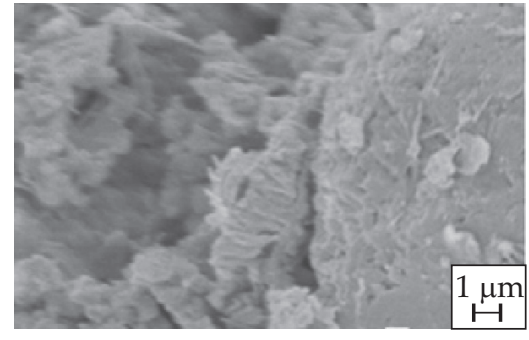

d)

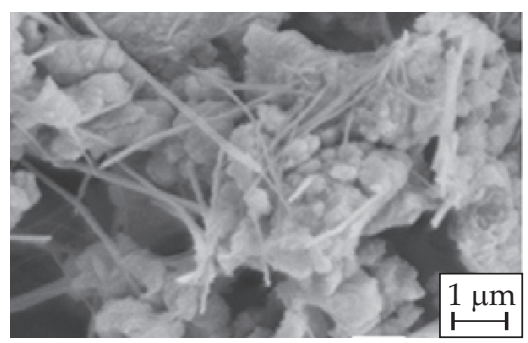

b)

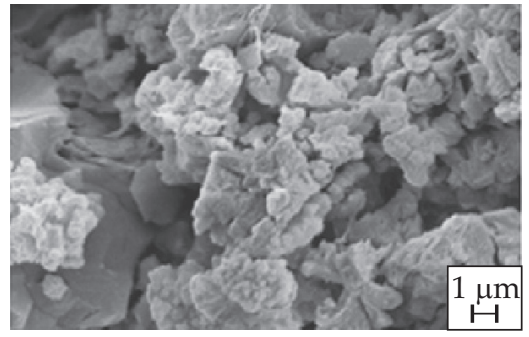

e)

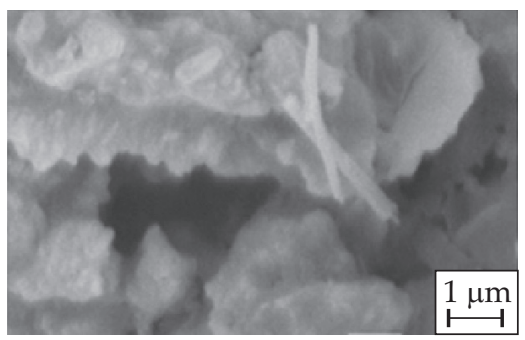

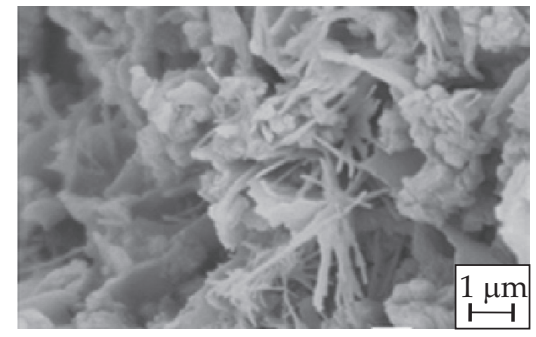

f)

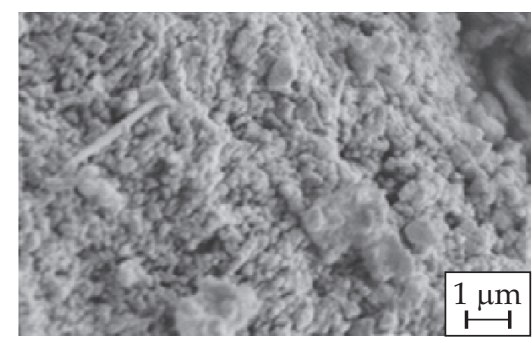

Fig. 4. SEM images of mortar samples illustrating different textures obtained using various additives: a) blank sample, b) caseine, c) animal glue, d) nopal as powder, e) nopal as mucilage, f) olive oil [1] 
viscosities compared to the dian resins, which is related to the ease of penetration into the porous material for comparable reinforcing efficiency. Although not containing UV-sensitive aromatic groups, cycloaliphatic epoxy polymers may suffer gradual photodegradation, discoloration and cracking as it was shown both in natural and artificial aging investigations. FT-IR analyses indicated that a degradation mechanism involves the opening of cyclic structures, chain scissions, and hydrogen abstractions from the polymer backbone [20]. Another way to overcome the limitations of epoxy resins are hybrid systems such as epoxy-silica materials based on glycidoxy functional silanes [21] or tetraethoxysilane (TEOS) added to polysiloxane epoxy resin [22]. TEOS plays a dual role, reducing the viscosity of the formulation and contributing to the mechanical properties of the film without causing cracking. However, epoxy-silica systems exhibit limited resistance to weathering and prolonged contact with water [23].

Acrylic polymers are frequently used for the preservation of monuments, primarily for strengthening stone elements and filling cavities [24, 25]. The most important are copolymers of acrylic and methacrylic acid esters as well as polymethyl methacrylate and butyl polymethacrylate, i.e. thermoplastic polyacrylates. They are characterized by good solubility in organic liquids, excellent transparency, resistance to light, moisture and microorganisms. A biodegradable polyester, high molecular weight poly(lactide) was used as protective coating on marble reducing gypsum formation on marble surfaces in the polluted environment [26]. A very promising direction of research is application of hybrid coatings containing nanoparticles mixed with commercial polymers, that can produce superhydrophobic surfaces [27]. Amphiphilic block copolymers synthesized from acrylic monomers by means of the RAFT controlled polymerization method are combined with inorganic nanoparticles (including UV-blocking titania and zinc oxide) resulting in hybrid nanocomposite materials for either protective or consolidating treatments of stone. The preliminary tests of colloidal polymer dispersions applied onto sandstone and marble surfaces showed that very low amounts of the applied polymer are sufficient to make the stone surface hydrophobic [28].

Among the silane derivatives, the most important are alkylsilanes, more specifically tetraalkoxysilane and the products of its partial condensation. They are basic components of the compositions for reinforcing porous materials, on the other hand they are not able to provide any hydrophobic properties (the resulting silica is hydrophilic). The effect of hydrophobization can be obtained using alkyltriethoxysilanes, e.g. methyltriethoxysilane. The resulting polysiloxane is bound with the inorganic substrate in such a way that the alkyl groups are directed upwards [29].

In the conservation practice, silicone microemulsions based on alkoxy and alkyl alkoxysilanes as active sub- stances are often used, especially for hydrophobization. An additional effect of material strengthening may occur when using some emulsions, however, this is not the main goal of their application. Recent advances in alkoxysilane-based consolidants for stone were reviewed by $\mathrm{Xu}$ et al. [30]. Many studies have been devoted to preventing the cracking of silica gel formed by the hydrolysis of silane. One of the successful approaches was introducing elastic segments by incorporation of low molecular weight hydroxyl-terminated polydimethylsiloxane (PMDS-OH). Other solutions include reducing capillary pressure by adding a surfactant or using nanoparticles to increase gel pore diameter.

Also, silicone resins are used in the conservation of stone buildings, primarily for the hydrophobization of porous materials such as limestone and sandstone. Usually, these are modified poly (dimethyl siloxanes), soluble in aliphatic hydrocarbons, and their crosslinking takes place under the influence of moisture, due to the presence of groups reacting easily with water. Siliconates were also used to preserve monuments, but the problem was a large amount of by-products in the form of sodium and potassium carbonate, which damages the stone [31].

The advantage of silicone-based treatments is due to the fact that they provide a barrier against water penetration, while not limiting the diffusion of water vapor and allowing the walls to "breathe". Siloxane molecules, with relatively long $\mathrm{Si}-\mathrm{O}$ and $\mathrm{Si}-\mathrm{C}$ bonds, exhibit high flexibility resulting in free rotation and spatial orientation of the polymer with respect to the substrate. The alkyl substituents form a hydrophobic layer, which repels water without affecting water vapor permeability. In contrast, acrylic systems are much less permeable to gases and vapors, which causes unfavorable sealing of the building material [32]. In order to achieve high surface hydrophobicity and water resistance combined with good water vapor permeability hybrid silicone-acrylic dispersions can be used [33].

Fluoropolymers are organic polymers containing carbon-fluorine bonds, which results in increased resistance to decay factors. For conservation of stone elements, fluorinated oils, i.e. perfluorovinylether polyethers with low degree of polymerization are of the largest importance. They are characterized by significant chemical and biological resistance as well as hydrophobicity. For some time, fluorinated polyamides and polyurethanes were also used, which in addition to hydrophobicity and oxidation resistance, have good adhesion to stone substrates [34]. The evaluation of synthetic coatings based on commercially available siloxane-, siloxane/acrylic-and perfluoroetherbased compositions in the protection of stone monuments of Hellenistic and Byzantine period was reported in the study of Cappelletti et al. [35]. Hybrid systems based on siloxane-containing polymer matrices modified with fluoropolymer or acrylic resins were examined as coatings for the protection of porous limestone substrate [36]. The selection of an organic component was critical to the wa- 
ter vapor permeability, water absorption and weathering resistance of the coatings, being the key parameters in the protection of building materials. Another field of polymer application are anti-grafitti coatings, which produce low energy surfaces that make the substrate water- and oil-repellent, however, they are more often used to the modern than historic buildings [37, 38].

The hydrophobic conservation treatment may damage the stone materials, especially those with weak compressive strength and large water adsorption coefficient. This damage is a result of the differences in thermal and moisture deformations between the hydrophobic part of the conserved stones and the hydrophilic part in the bulk stones. In order to reduce these side effects of the conservation process double layer or multilayer conservation methods are proposed [39].

The difficulties and solutions found during the evaluation of performances of different conservation treatments in a real case of restoration were discussed in the paper of Vecchiattini et al. In order to face the problem of the low porosity of the material, marly lime stone ashlars of the Abbey of San Fruttuoso di Capodimonte (Genoa, Italy), many different classes of products, both inorganic and organic, including silane/siloxane, acrylic and fluoroelastomer polymers with different mechanism of action and their combinations, have been assessed as consolidating and protective treatments [40].

Another example of an application of polymers in the conservation of ancient masonry is hydrophobization treatment, that was applied in the Tyritake archeological site in the city of Kerch (Crimea). The conservation works were conducted as a part of the international project "The Bosporan City Tyritake" which included not only the archaeological research but also a comprehensive geological, urban, paleozoological and paleobotanical analysis of the ancient city territory. The leading organization of the Polish Archeological Campaign was the National Museum in Warsaw and the conservation work was handled by the Civil Engineering Faculty of the Warsaw University of Technology in years from 2011 to 2013 [41-43]. The oligomer siloxane solution was applied to the selected lime masonry walls in the archeological site. The measurement of a water absorption showed a good performance of the applied treatment. However, the durability of this solution should be examined in detail. This kind of protection is considered as not permanent one and the losses of impregnation performance should be followed by repetition of treatment.

\section{TRENDS IN CONSERVATION}

One of the observed trends in a modern approach to the investigation of mortars used in conservation of ancient structures is a need for a better understanding of the influence of historical techniques to material properties. It could result in a replacement of modern synthetic admixtures by the bio-admixtures that are more compati- ble with an original structure. The organic admixture can be used to enhance the mechanical properties and durability of the mortars that are used in the conservation of the heritage structures. It could be considered as a biodegradable, regionally available and inexpensive substitution of synthetic admixtures [44]. Moreover, the reversible rate of conservation materials is nowadays started to be measured. On the base of researches [45] the reversible rate of each conservation material was measured based on hydrogel cleaning. It was found that the gel filled with cleaning agents showed excellent performance over the empty gel. Besides, it was more environment-friendly without mechanical damage to the sensitive surface and easier to control the cleaning process compared with pure organic solvent cleaning.

Another promising direction in the development of polymeric materials for the preservation of historic stone buildings is the applications of nanofillers, which added at low concentrations, can significantly improve mechanical properties and protective performance of the polymer films. The effects of nanometric silica, alumina and aluminosilicates on the rheological, mechanical and barrier properties of various polymer matrices in the context of their application in the field of the Cultural Heritage preservation was discussed in the work of Frigione and Lettieri [46].

\section{CONCLUSION}

Conservation of ancient stone masonry structures is a complicated and complex issue due to the diverse structure of the walls and various properties of the materials from which they are made. It has a significant impact on the durability of the structure and the resulting degree of their preservation. Since ancient times natural polymers had been widely used in constructions, improving the physical and mechanical properties of the walls. Nowadays, those ancient techniques are implemented in a conservation work due to the requirement of a compatibility with original structures. That evokes the necessity of an understanding of the specific processes that stands behind the efficiency of historical techniques. On the other hand, synthetic polymers are often used, mainly for reinforcing and hydrophobization activities, preserving the need for a limited and reversible effect on the structure of the primary material. The use of synthetic polymers in the preservation of stone masonry structures is a promising activity. The introduction of new materials and technologies requires further research, in which attention must be paid to the principles of selection of the materials with respect to the originally used, historical material.

\section{REFERENCES}

[1] Ventol L., Vendrell M., Giraldez P. et al.: Construction and Building Materials 2011, 25, 3313.

https://doi.org/10.1016/j.conbuildmat.2011.03.020 
[2] Thomas L.H., Forsyth V.T., Sturcova A. et al.: Plant Physiology 2013, 161, 465. https://doi.org/10.1104/pp.112.206359

[3] Chandra S.: Cement-Lime-Concrete 2010, 15, 31.

[4] Fang S.Q., Zhang H., Zhang B.J.: Journal of Cultural Heritage 2014, 15, 144.

http://dx.doi.org/10.1016/j.culher.2013.04.001

[5] Rao H., Li B., Yang Y. et al.: Analytical Methods 2015, 7, 143. http://dx.doi.org/10.1039/C4AY01766H

[6] Fang S., Zhang K., Zhang H. et al.: Cement and Concrete Research 2015, 76 C, 232. http://dx.doi.org/10.1016/j.cemconres.2015.06.006

[7] Chandra S., Aavik J.: International Journal of Cement Composites and Lightweight Concrete 1987, 9, 91. https://doi.org/10.1016/0262-5075(87)90024-8

[8] Crhova M., Kuckova S., Hynek R. et al.: "Proteomic identification of milk proteins in historical mortars", Proceedings pro078 : 2nd Conference on Historic Mortars - HMC 2010 and RILEM TC 203-RHM final workshop (Eds. Válek J., Groot C., Hughes J.J.) 2010, pp. 91-97.

[9] Zhang B., Hu W., Zhang S. et al.: Journal of Building Materials 2015, 18 (4), 716. http://dx.doi.org/10.3969/j.issn.1007-9629.2015.04.031

[10] Mydin O.: Journal of Materials and Environmental Sciences 2018, 9 (2), 376. https://doi.org/10.26872/jmes.2018.9.2.41

[11] Ravi R., Thirumalini S.: International Journal of Architectural Heritage 2019, 13, 229. http://dx.doi.org/10.1080/15583058.2018.1431732

[12] Liu X., Ma Q., Zhang B.: International Journal of Architectural Heritage 2016, 10, 663. http://dx.doi.org/10.1080/15583058.2015.1104399

[13] Yang T., Ma X., Zhang B., Zhang H.: Construction and Building Materials 2016, 102, 105. https://doi.org/10.1016/j.conbuildmat.2015.10.183

[14] Ravi R., Selvaraj T., Sekar S.K.: International Journal of Architectural Heritage 2016, 10, 714. http://dx.dfoi.org/10.1080/15583058.2015.1109735

[15] Luo W., Li T., Wang C., Huang F.: Journal of Archaeological Science 2012, 39, 1227. http://dx.doi.org/10.1016/j.jas.2011.12.035

[16] Selwitz Ch.: "Stone conservation. An Overview of current research", The Getty Conservation Institute, Washington 1992.

[17] Domaslowski W.: Monumentum 1969, 4, 51.

[18] Selwitz Ch.: "Epoxy Resins in Stone Conservation", The Getty Conservation Institute, Washington 1992.

[19] Moncrieff A., Hempel K.F.B.: Studies in Conservation 1977, 22, 1. http://dx.doi.org/10.2307/1505669

[20] Tesser E., Lazzarini L., Bracci S.: Journal of Cultural Heritage 2018, 31, 72. http://dx.doi.org/10.1016/j.culher.2017.11.002

[21] Cardiano P., Sergi S., Lazzari M, Piraino P.: Polymer 2002, 43, 6635.
https://doi.org/10.1016/S0032-3861(02)00677-8

[22] Tulliani J.M., Formia A., Sangermano M.: Journal of Cultural Heritage 2011, 12, 364.

https://doi.org/10.1016/j.culher.2011.04.001

[23] Briffa S.M., Vella D.A.: Heritage Science 2019, 7, 30. https://doi.org/10.1186/s40494-019-0270-1

[24] Mazzola M., Frediani P., Bracci S. et al.: European Polymer Journal 2003, 39, 1995.

https://doi.org/10.1016/S0014-3057(03)00110-1

[25] Tabasso M.L.: APT Bulletin: The Journal of Preservation Technology, Preservation of Historic Masonry 1995, 26, 17. http://dx.doi.org/10.2307/1504445

[26] Ocak Y., Sofuoglu A., Tihminlioglu F. et al.: Progress in Organic Coatings 2016, 66, 213. https://doi.org/10.1016/j.porgcoat.2009.07.007

[27] Cappelletti G., Fermo P.: "Smart Composite Coatings and Membranes" (Ed. Montemor M.F.), Elsevier Inc., Amsterdam, The Netherlands 2016, pp. 421-452. https://doi.org/10.1016/B978-1-78242-283-9.00015-4

[28] Lazzeri A., Bianchi S., Castelvetro V. et al.: "Science and Art: A Futur for Stone (Eds. Hughes J.J., Howind T.): Proceedings of the 13th International Congress on the Deterioration and Conservation of Stone, Volume 1. Paisley, University of the West of Scotland, 2016, pp. 855-862.

[29] Wheeler G., Goins E.S.: "Stone Conservation: An Overview of Current Research", Getty Conservation Institute, 2015.

[30] Xu F., Zeng W., Li D.: Progress in Organic Coatings 2019, 127, 45.

https://doi.org/10.1016/j.porgcoat.2018.11.003

[31] Tarasov V.I.: Russian Journal of Applied Chemistry 2001, 74, 1985.

[32] Zielecka M., Miazga A.: Ochrona przed korozją 2005, 1, 25.

[33] Kozakiewicz J., Trzaskowska J., Domanowski W. et al.: Coatings 2019, 9, 25.

[34] Ciabach J.: „Właściwości żywic sztucznych stosowanych w konserwacji zabytków", Uniwersytet im. Mikołaja Kopernika, Torun 1997.

[35] Cappelletti G., Fermo P., Camiloni M.: Progress in Organic Coatings 2015, 78, 511. http://dx.doi.org/10.1016/j.porgcoat.2014.05.029

[36] Zielecka M., Bujnowska E., Bajdor K.: Journal of Coatings Technology and Research 2007, 4 (3), 275. https://doi.org/10.1007/s11998-007-9028-x

[37] Dobkowski Z., Zielecka M.: Polimery 2001, 46, 835. http://dx.doi.org/10.14314/polimery.2001.835

[38] Mańczyk K., Mańczyk K., Trzebicka B., Dworak A.: Polimery 2008, 53, 830. http://dx.doi.org/10.14314/polimery.2008.830

[39] Zhang H., Liu Q., Liu T., Hang B.: Progress in Organic Coatings 2013, 76, 1127. http://dx.doi.org/10.1016/j.porgcoat.2013.03.018

[40] Vecchiattini R., Fratini F., Rescic S. et al.: Journal of Cultural Heritage 2018, 34, 1.

https://doi.org/10.1016/j.culher.2018.01.019 
[41] Terlikowski W., Wasilewski K.: "PROHITECH'14" (Eds. Mazzolani F.M., Altay G.): Proceedings of the 2nd International Conference on Protection of Historical Constructions, Bogazici University, Istanbul 2014: pp. 759-766.

[42] Terlikowski W., Wasilewski K.: “Tyritake. Antique Site at Cimmerian Bosporus" (Ed. Twardecki A.): Proceedings of the International Conference, National Museum Warsaw, Warsaw 2014, pp. 83-95.

[43] Terlikowski W., Wasilewski K., Sobczyńska E., Gregoriou-Szczepaniak M.: "Approach to conserva- tion of irregular stone masonry based on archaeological excavations in the Black Sea basin", E3S Web of Conferences, 2018, p. 49.

[44] Zhu Y., Romain C., Williams C.K.: Nature 2016, 540, 354.

[45] Sun M., Zou J., Zhang H., Zhang B.: Journal of Cultural Heritage 2015, 16, 719.

[46] Frigione M., Lettieri M.: Coatings 2018, 8, 319. https://doi.org/10.3390/coatings8090319

Received 11 III 2019.

Revised version 23 X 2019. 